\title{
EGF receptor-mediated intracellular calcium increase in human hepatoma BEL-7404 cells ${ }^{1}$
}

\author{
FU $\mathrm{T}_{\mathrm{AO}} *, \mathrm{Y}_{\mathrm{ONGHUA}} \mathrm{XU} *, \mathrm{~W}_{\mathrm{ANL}} \mathrm{J} \mathrm{JANG}^{*}, \mathrm{H}_{\mathrm{ONG}} \mathrm{YU}$ \\ $\mathrm{ZHANG}^{*}, \mathrm{P}_{\text {E I Hon }} \mathrm{ZHU} * *, \mathrm{~J}_{\mathrm{UN}} \mathrm{WU}^{* *}$ \\ *Laboratory of Cellular and Molecular Oncology, Shanghai \\ Institute of Cel1 Biology, **Shanghai Institute of Phy- \\ siology, Chinese Academy of Sciences, Shanghai 200031, \\ China.
}

\section{ABSTRACT}

Epidermal growth factor (EGF) induced intracellular free calcium $\left(\left[\mathrm{Ca}^{2+}\right]_{i}\right)$ response was studied in fura-2- or fluo-3-loaded human hepatoma cells of BEL-7404 cell line. Single cell $\left[\mathrm{Ca}^{2+}\right]_{\mathrm{i}}$ analysis and $\left[\mathrm{Ca}^{2+}\right]_{\mathrm{i}}$ measurement in cell populations revealed that EGF triggered a rapid $\left[\mathrm{Ca}^{2+}\right]_{\mathrm{i}}$ increase in the dose-dependent and time- dependent manner. Pretreatment of cells with an endoplasmic reticulum (ER) $\mathrm{Ca}^{2+}$-ATPase inhibitor, thapsigargin (TG) at $100 \mathrm{nM}$ concentration for $20 \mathrm{~min}$, completely abolished EGF-induced $\left[\mathrm{Ca}^{2+}\right]_{\mathrm{i}}$ increase, and chelating extracellular calcium by excess EGTA partially inhibited the increase. Furthermore, the expression of antisense EGF receptor sequence in BEL-7404 cells suppressed the $\left[\mathrm{Ca}^{2+}\right]_{i}$ response to EGF. The results suggest that EGF receptor-mediated $\left[\mathrm{Ca}^{2+}\right]_{\mathrm{i}}$ increase in the human hepatoma ceils is essentially dependent on the $\mathrm{Ca}^{2+}$ storage in ER.

Key words: EGF receptor, calcium, thapsigargin, human hepatoma cells.

\section{INTRODUCTION}

Epidermal growth factor (EGF) and its receptor are key regulatory components

1. The project is supported by China Postdoctoral Science Foundation and Shanghai Joint Laboratory of Life Science Foundation 
EGF receptor-mediated calcium increase in hepatoma cells

of cell growth and differentiation in a variety of cell types[1]. The EGF receptor tyrosine kinase- mediated signal transduction pathways have been suggested to play the pivotal role under either physiological condition or pathological condition, for example, cancer. Among the multiple signal transduction pathways, EGF induces the intracellular free calcium $\left(\left[\mathrm{Ca}^{2+}\right]_{\mathrm{i}}\right)$ increase in several cell types, but the underlying mechanism is so far unresolved. In some situation, the $\left[\mathrm{Ca}^{2+}\right]_{\mathrm{i}}$ response has been considered to be linked to the hydrolysis of polyphosphoinositides by phospholipase $\mathrm{C}_{\gamma}$, which is activated as a result of phosphorylation on tyrosine residues by the EGF receptor tyrosine kinase[2]. As a consequence, the second messengers 1,2diacylglycerol and inositol-1, 4, 5-trisphosphate are produced. The former activates protein kinase $\mathrm{C}$ and the latter releases $\mathrm{Ca}^{2+}$ from internal stores in endoplasmic reticulum $[3,4]$. Besides the induction of internal $\mathrm{Ca}^{2+}$ release, $\mathrm{EGF}$ induces the $\mathrm{Ca}^{2+}$ influx through the plasma membrane in some cell types. In these cells, the activation of the $\mathrm{Ca}^{2+}$ channels by EGF stimulation is independent of phospholipase $\mathrm{C}$, but mediated by the activation of phospholipase $\mathrm{A}_{2}$ [5]. In the previous studies, we have demonstrated the EGF receptor gene expression and mitogenic effects of EGF in cells of a human hepatoma cell line BEL-7404[6]. We have recently obtained a cell clone, which constitutively expresses the antisense EGF receptor sequence, from BEL-7404 cells[7]. These cell lines might be useful for studying the signalling of EGF.

In the present study, the effects of EGF on $\left[\mathrm{Ca}^{2+}\right]_{\mathrm{i}}$ were examined in BEL-7404 cells and its derivatives by using the $\left[\mathrm{Ca}^{2+}\right]_{\mathrm{i}}$ measurement in cell populations combined with single-cell $\left[\mathrm{Ca}^{2+}\right]_{\mathrm{i}}$ analysis. The dependency of EGF-induced $\left[\mathrm{Ca}^{2+}\right]_{\mathrm{i}}$ responses on extracellular $\mathrm{Ca}^{2+}$ concentration and intracellular $\mathrm{Ca}^{2+}$ storages was also studied.

\section{MATERIALS AND METHODS}

\section{Materials}

Fluo-3/AM, fura-2/AM, thapsigargin were perchased from Sigma (St. Louis, MO, USA). EGF was from Gibco BRL (Gaithersburg, MD, USA). All other chemicals were from commercial sources.

\section{Cell Culture}

Human hepatoma cell line BEL-7404 cells and an antisense EGF receptor-expressed cell clone derived from BEL-7404 cells were grown in Dulbecco's modified Eagle's medium (DMEM, Gibco, Grand Island, NY, USA) supplemented with $13 \%$ fetal calf serum, $100 \mu / \mathrm{ml}$ of penicillin and 100 $\mu \mathrm{g} / \mathrm{ml}$ of streptomycin in $5 \% \mathrm{CO}_{2}$ incubator. After being cultured at $37{ }^{\circ} \mathrm{C}$ for $48 \mathrm{~h}$, the cells were kept in the serum-free medium for $24 \mathrm{~h}$ before the determinations unless otherwise indicated.

\section{Measurement of intracellular free $\mathrm{Ca}^{2+}$ concentration}

For single-cell $\left[\mathrm{Ca}^{2+}\right]_{\mathrm{i}}$ microspectrofluorimetry, cells were plated at a density of $1 \times 10^{4}$ cells/well on the 6-well Nunclon plate inserted with sterile glass coverslips. After the cells were cultured on the condition indicated above, the coverslips were incubated with assay buffer $(\mathrm{NaCl} 125 \mathrm{mM}, \mathrm{KCl} 5$ $\mathrm{mM}, \mathrm{CaCl}_{2} 1 \mathrm{mM}, \mathrm{MgCl}_{2} 1 \mathrm{mM}$, Glucose $10 \mathrm{~m} M$, HEPES $25 \mathrm{mM}, \mathrm{pH} 7.05$ and $0.1 \%$ bovine serum albumin) containing fura-2/AM $(5 \mu M)$ at $37^{\circ} \mathrm{C}$ for $45 \mathrm{~min}$. At the end of the incubation, the 
coverslips were mounted on the recording chamber of a microscope equipped for microfluorimetry as described previovusly[8].Fluorescence intensity was obtained with dual excitation wavelengths set at 350 and $380 \mathrm{~nm}$ and emission wavelength at $510 \mathrm{~nm}$,respectively $\left[\mathrm{Ca}^{2+}\right]_{\mathrm{i}}$ was valued from the $350 \mathrm{~nm} / 380 \mathrm{~nm}$ fluorescence ratios.

For measurement of $\left[\mathrm{Ca}^{2+}\right]_{i}$ in cell populations, the cells were incubated with the assay buffer containing fluo-3/AM $(5 \mu \mathrm{M})$ at $37^{\circ} \mathrm{C}$ for $30 \mathrm{~min}$. At the end of the loading, the cells were detached by the treatment with $0.125 \%$ trypsin in $\mathrm{Ca}^{2+}$-free and $\mathrm{Mg}^{2+}$-free Hank's solution for $3 \mathrm{~min}$. After centrifugation at $250 \times \mathrm{g}$ for $3 \mathrm{~min}$, the cell pellet was resuspended in $1 \mathrm{ml}$ of the assay buffer. The fluorescence of individual cells was measured using a FACStar Plus flow cytometer (Becton and Dickinson, CA, USA). For each assay, 2,500 cells were examined and the mean value was taken. All the data were recorded and analyzed using specific FACStar research software. The change of $\left[\mathrm{Ca}^{2+}\right]_{\mathrm{i}}$ was expressed as $\triangle \mathrm{F} / \mathrm{F}(\%)$, the percentage of actual fluorescence to the control fluorescence level in unstimulated state.

\section{RESULTS}

1. EGF induced $\left[\mathrm{Ca}^{2+}\right]_{\mathrm{i}}$ increase in human hepatoma BEL-7404 cells

Measurement of $\left[\mathrm{Ca}^{2+}\right]_{\mathrm{i}}$ in cell populations loaded with fluorescent indicator fluo3 demonstrated that EGF elicited the increase of fluorescence intensity, which reflected the increase of $\left[\mathrm{Ca}^{2+}\right]_{i}$, in a dose-dependent manner, with the maximal dose around $300 \mathrm{ng} / \mathrm{ml}$ (Fig 1). Different doses (from $3 \mathrm{ng} / \mathrm{ml}$ to $300 \mathrm{ng} / \mathrm{ml}$ ) of EGF produced different magnitudes but similar kinetics of $\mathrm{Ca}^{2+}$ signals (see Fig 1, inset). Therefore, in the following experiments, the maximal dose $(300 \mathrm{ng} / \mathrm{ml})$ of EGF was used unless otherwise indicated. Single-cell $\left[\mathrm{Ca}^{2+}\right]_{\mathrm{i}}$ measurement in fura-2-1oaded cells revealed that EGF $(300 \mathrm{ng} / \mathrm{ml})$ induced the transient $\left[\mathrm{Ca}^{2+}\right]_{\mathrm{i}}$ increase in BEL7404 cells (Fig 2). The peak of $\left[\mathrm{Ca}^{2+}\right]_{\mathrm{i}}$ response was observed around $1 \mathrm{~min}$ after EGF application, and the ratio $(350 \mathrm{~nm} / 380 \mathrm{~nm})$ increased about 3 -fold. Then, the $\left[\mathrm{Ca}^{2+}\right]_{\mathrm{i}}$ level rapidly decreased within 2 min of the stimulation. As shown in Fig 3 a, EGF (300 ng /ml) induced the rapid increase of $\left[\mathrm{Ca}^{2+}\right]_{\mathrm{i}}$ in cell populations, which was initially identical to that obtained in single-cell $\left[\mathrm{Ca}^{2+}\right]_{i}$ measurement except a slow falling phase following the $\left[\mathrm{Ca}^{2+}\right]_{i}$ peak.

Fig 1. Dose-dependence increase of EGF-induced $\left[\mathrm{Ca}^{2+}\right]_{\mathrm{i}}$ in fluo-3loaded BEL7404 cells with flow cytometry. $\left[\mathrm{Ca}^{2+}\right]_{i}$ levels were measured in cell populations after the application of indicated doses of EGF for $1 \mathrm{~min}$. Inset, $\left[\mathrm{Ca}^{2+}\right]_{\mathrm{i}}$ levels were recorded in cell populations after application of different doses of EGF ( 3 , 30 and $300 \mathrm{ng} / \mathrm{ml}$, respectively) for indicated periods.

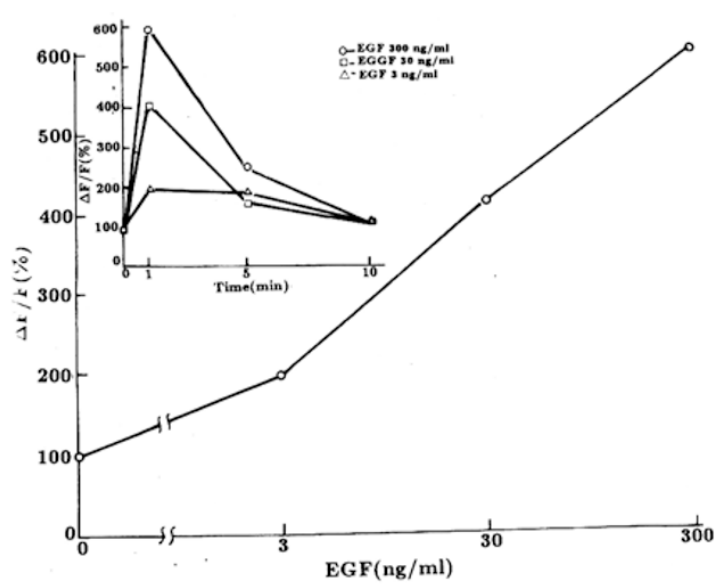


EGF receptor-mediated calcium increase in hepatoma cells

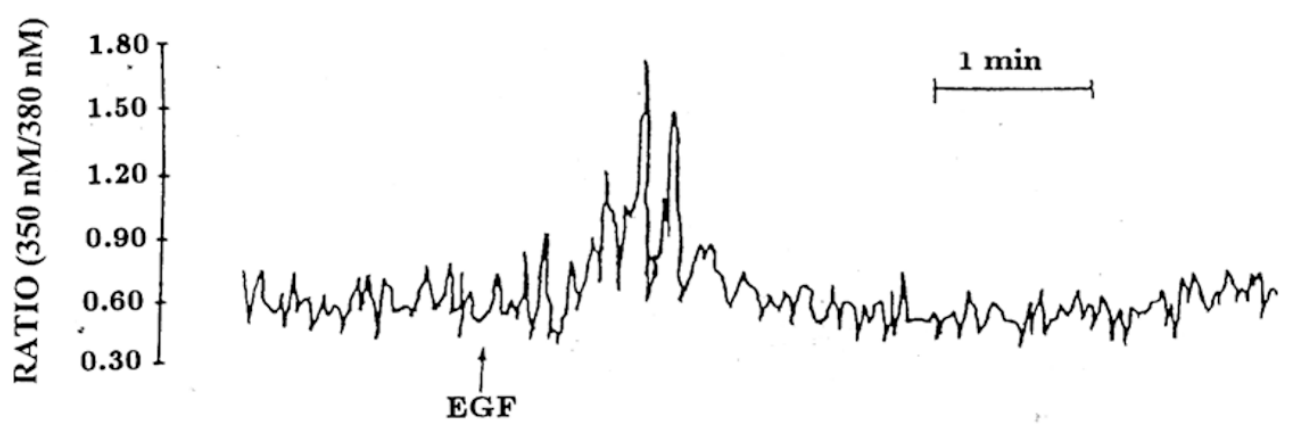

Fig 2. EGF-induced $\left[\mathrm{Ca}^{2+}\right]_{\mathrm{i}}$ increase in fura-2-1oaded BEL-7404 cells measured by microspectrofluorimetry with single-cell $\left[\mathrm{Ca}^{2+}\right]_{\mathrm{i}}$ measurement. EGF (300 ng/ml) was added at the point indicated by arrow.

2. Dependency of EGF-induced $\left[\mathrm{Ca}^{2+}\right]_{\mathrm{i}}$ increase on extracellular $\mathrm{Ca}^{2+}$ concentration

As shown in Fig $3 \mathrm{~b}$, in $\mathrm{Ca}^{2+}$-free assay buffer, pretreatment of cells with $1 \mathrm{mM}$ EGTA for 3 min partially inhibited the EGF-induced $\left[\mathrm{Ca}^{2+}\right]_{\mathrm{i}}$ increase, especially in the early stage, for example 1 min after the stimulation, the inhibition was about $50 \%$ as compared with the $\left[\mathrm{Ca}^{2+}\right]_{\mathrm{i}}$ response in $1 \mathrm{mM} \mathrm{Ca}^{2+}$-containing assay buffer. The results suggested the contribution of $\mathrm{Ca}^{2+}$ influx to the total $\left[\mathrm{Ca}^{2+}\right]_{i}$ increase was triggered b y EGF.

Fig 3. Effect of extracellular $\mathrm{Ca}^{2+}$ on

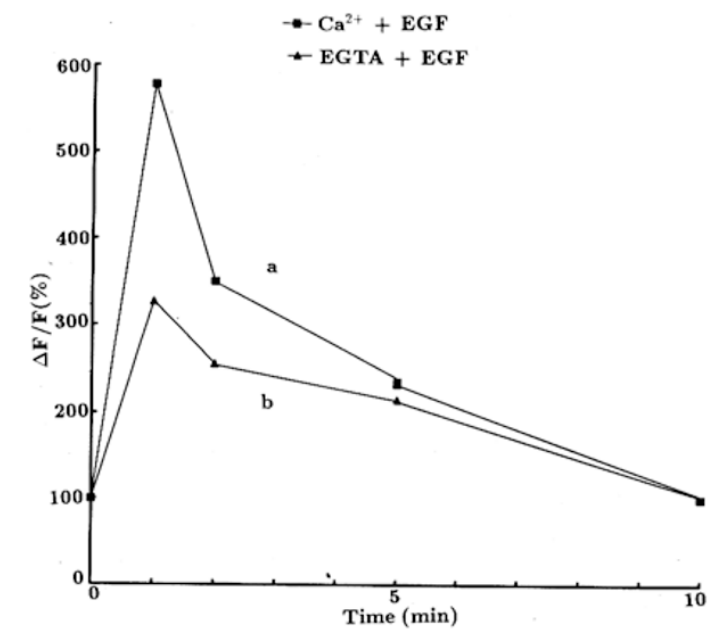
EGF-induced $\left[\mathrm{Ca}^{2+}\right]_{\mathrm{i}}$ increase in fluo-3-1oaded BEL-7404 cells. (a), $\left[\mathrm{Ca}^{2+}\right]_{\mathrm{i}}$ levels were measured in cell populations after the application of EGF ( 300 $\mathrm{ng} / \mathrm{ml}$ ) for $1,2,5,10 \mathrm{~min}$ respectively, in the presence of 1 $\mathrm{mM} \mathrm{Ca}{ }^{2+}$. (b), the cells were preincubated in $\mathrm{Ca}^{2+}$-free assay buffer containing $1 \mathrm{mM}$ EGTA for $3 \mathrm{~min}$, and then $\left[\mathrm{Ca}^{2+}\right]_{\mathrm{i}}$ levels were measured in cell populations after the addition of EGF (300 ng/ml) to the above buffer for indicated periods. 
3. The effects of thapsigargin on $\left[\mathrm{Ca}^{2+}\right]_{\mathrm{i}}$ with or without the EGF stimulation

As expected, thapsigargin (TG) at $100 \mathrm{nM}$ concentration did produce the pronounced $\left[\mathrm{Ca}^{2+}\right]_{i}$ increase in human hepatoma BEL-7404 cells (Fig 4A). In the $\mathrm{Ca}^{2+}$ free assay buffer, TG also induced some $\left[\mathrm{Ca}^{2+}\right]_{\mathrm{i}}$ increase but to a much less extent (Fig 4B). Interestingly, when $1 \mathrm{mM} \mathrm{Ca}{ }^{2+}$ was re-added to the above sample, the $\left[\mathrm{Ca}^{2+}\right]_{\mathrm{i}}$ was rapidly elevated again to the level comparable to the peak of early $\left[\mathrm{Ca}^{2+}\right]_{\mathrm{i}}$ response in the cells incubated with $100 \mathrm{nM}$ TG in $1 \mathrm{mM} \mathrm{Ca}{ }^{2+}$-containing assay buffer, which suggested that $\mathrm{Ca}^{2+}$ influx could occur as a consequence of the TG- induced $\mathrm{Ca}^{2+}$ store depletion.

Fig 4. Effects of TG $(100 \mathrm{n} M)$ on $\left[\mathrm{Ca}^{2+}\right]_{\mathrm{i}}$ in fluo-3-loaded BEL7404 cells. $\left[\mathrm{Ca}^{2+}\right]_{i}$ levels were measured in cell populations.

A, TG was added into the assay buffer containing $1 \mathrm{mM} \mathrm{Ca}{ }^{2+}$, and $\left[\mathrm{Ca}^{2+}\right]_{\mathrm{i}}$ levels were recorded after the application of TG for $1,5,10,20 \mathrm{~min}$, respectively. $\mathrm{B}$, Before stimulation, the cells were washed twice with $1 \mathrm{mM}$ EGTA-containing $\mathrm{Ca}^{2+}$-free assay buffer. TG was added into $\mathrm{Ca}^{2+}$-free assay buffer for 10 min, then $1 \mathrm{mM} \mathrm{Ca}{ }^{2+}$ was readded into the sample at the point indicated by arrows. Measurements of $\left[\mathrm{Ca}^{2+}\right]_{i}$ were performed at the points as shown in the figure.
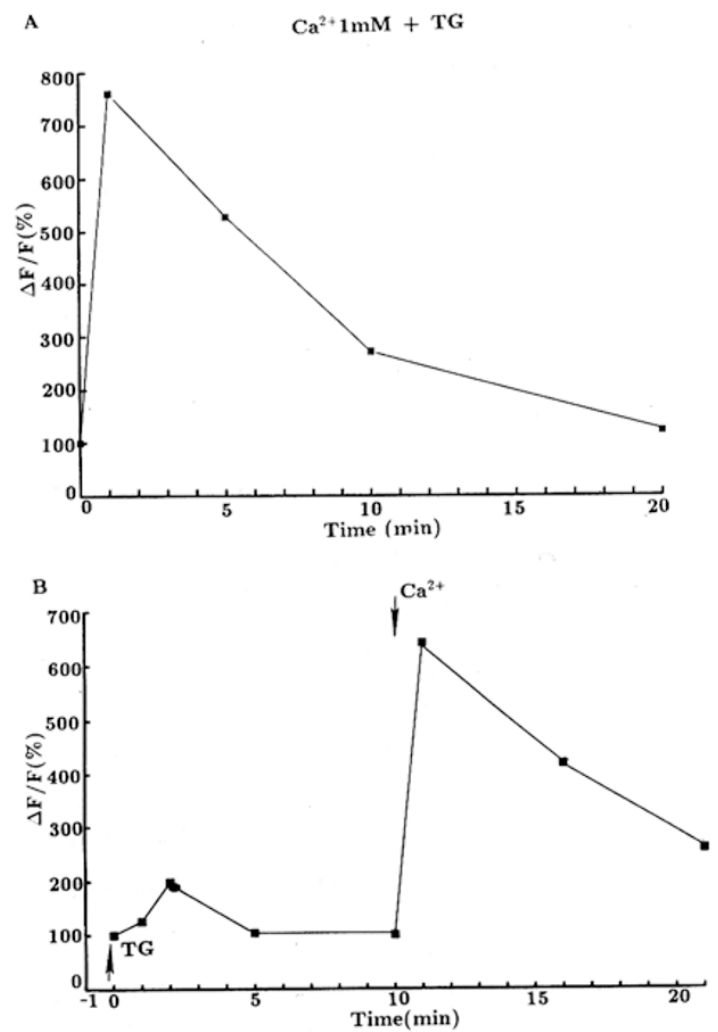
EGF receptor-mediated calcium increase in hepatoma cells

In order to investigate the contribution of intracellular $\mathrm{Ca}^{2+}$ storage to the EGFinduced $\left[\mathrm{Ca}^{2+}\right]_{\mathrm{i}}$ increase, we did some $\left[\mathrm{Ca}^{2+}\right]_{\mathrm{i}}$ measurements either through the addition of EGF (300 ng/ml) to suspended human hepatoma BEL-7404 cells pretreated with TG ( $100 \mathrm{nM})$ for 20 min or through the addition of TG (100 $\mathrm{nM})$ to the cells pretreated with EGF ( $300 \mathrm{ng} / \mathrm{ml}$ ) for $10 \mathrm{~min}$. The data showed that the pretreatment with maximal dose of EGF ( $300 \mathrm{ng} / \mathrm{ml}$ ) for $10 \mathrm{~min}$ exhibited no inhibitory effect on TG-induced $\left[\mathrm{Ca}^{2+}\right]_{\mathrm{i}}$ increase, whereas preincubation with TG (100 $\mathrm{nM}$ for $20 \mathrm{~min}$ ) completely inhibited the EGF-induced $\left[\mathrm{Ca}^{2+}\right]_{i}$ increase in these cells (Tab 1).

Tab 1. Effects of TG and EGF on $\left[\mathrm{Ca}^{2+}\right]_{\mathrm{i}}$ in human hepatoma BEL-7404 cells*

\begin{tabular}{ll}
\hline Stimulations & $\triangle \mathrm{F} / \mathrm{F}(\%, \mathrm{M} \pm$ S.D. $)$ \\
\hline 1. EGF $300 \mathrm{ng} / \mathrm{ml}$, for $1 \mathrm{~min}$ & $579 \pm 26$ \\
2. TG $100 \mathrm{n} M$ for $1 \mathrm{~min}$ & $761 \pm 80$ \\
3. EGF $300 \mathrm{ng} / \mathrm{ml}$, for $10 \mathrm{~min}$, then & \\
a. addition of the buffer for $1 \mathrm{~min}$ & $101 \pm 8$ \\
b. addition of TG $100 \mathrm{n} M$ for $1 \mathrm{~min}$ & $706 \pm 32$ \\
4. TG $100 \mathrm{n} M$ for $20 \mathrm{~min}$, then & \\
a. addition of the buffer for $1 \mathrm{~min}$ & $120 \pm 8$ \\
b. addition of EGF $300 \mathrm{ng} / \mathrm{ml}$ for $1 \mathrm{~min}$ & $114 \pm 5$ \\
\hline
\end{tabular}

* $\left[\mathrm{Ca}^{2+}\right]_{\mathrm{i}}$ levels were measured in fluo-3-1oaded cell populations as described in "Materials and Methods", and all $\left[\mathrm{Ca}^{2+}\right]_{i}$ measurements were performed in the presence of $1 \mathrm{mM} \mathrm{Ca}{ }^{2+}$. (1) and (2), $\left[\mathrm{Ca}^{2+}\right]_{\mathrm{i}}$ levels were recorded after the application of either EGF $(300 \mathrm{ng} / \mathrm{ml})$ or TG (100 $\mathrm{nM}$ ) for $1 \mathrm{~min}$. (3), After the preincubation with EGF (300 ng/ml) for $10 \mathrm{~min}$, without washing, the assay buffer (100 $\mu \mathrm{l})$ was added in (a) and TG $(100 \mathrm{nM})$ was added in (b) 1 min before $\left[\mathrm{Ca}^{2+}\right]_{\mathrm{i}}$ measurements. (4), After the preincubation with TG (100 $\mathrm{nM}$ ) for $20 \mathrm{~min}$, without washing, the assay buffer (100 $\mu \mathrm{l})$ was added in (a) and EGF $(300 \mathrm{ng} / \mathrm{ml})$ was added in (b) $1 \mathrm{~min}$ before $\left[\mathrm{Ca}^{2+}\right]_{\mathrm{i}}$ measurement.

\section{Expression of antisense EGF receptor suppressed the EGF-induced $\left[\mathrm{Ca}^{2+}\right]_{\mathrm{i}}$ increase in human hepatoma BEL-7404 cells}

Recently, we have obtained a cell clone, JX-1, constitutively expressing the antisense EGF receptor sequence, and a control cell clone, JX-0, transferred with the vector plasmid in BEL-7404 cells[7]. We found that EGF-induced $\left[\mathrm{Ca}^{2+}\right]_{\mathrm{i}}$ increase in JX-1 cells were obviously inhibited in comparison with those in control JX-0 cells, although JX-0 cells showed a lower amplitude of $\left[\mathrm{Ca}^{2+}\right]_{\mathrm{i}}$ increase than that in BEL7404 cells for an unknown reason. When JX-1 cells were serum-starved for $24 \mathrm{~h}$, the $\left[\mathrm{Ca}^{2+}\right]_{\mathrm{i}}$ response to EGF stimulation were nearly abolished (Fig 5). Without serum-starvation, the EGF-induced $\left[\mathrm{Ca}^{2+}\right]_{\mathrm{i}}$ increase in JX-1 cells were inhibited by $29.5 \%$ to $50.3 \%$ in the presence of different doses of EGF (data not shown). 
$\mathrm{Fu} \mathrm{T}$ et al.

Fig 5. Increase of $\left[\mathrm{Ca}^{2+}\right]_{\mathrm{i}}$ induced by EGF in fluo-3-1oaded JX-0 and JX-1 cells. The cells were serum-starved for $24 \mathrm{~h}$ before the determinations and $\left[\mathrm{Ca}^{2+}\right]_{\mathrm{i}}$ was recorded after the application of indicated doses of EGF for $1 \mathrm{~min}$.

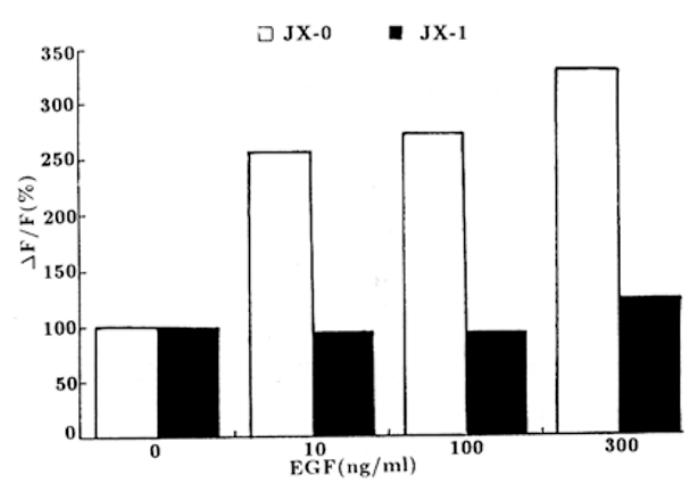

\section{DISCUSSION}

The use of fluorescent indicators sensitive to $\mathrm{Ca}^{2+}$ and readily introduced into cells represented a major advance in the measurement of $\left[\mathrm{Ca}^{2+}\right]_{i}$. The first of these, quin-2, has been largely superseded by fura-2[9]. Fluo-3, a more recent derivative, has the major advantage of having an excitation spectrum that is visible and thus does not require expensive quartz optics[10]. In the present study, a combination of single-cell $\left[\mathrm{Ca}^{2+}\right]_{\mathrm{i}}$ analysis with the $\left[\mathrm{Ca}^{2+}\right]_{\mathrm{i}}$ measurement in cell populations was made to resolve the regulation of EGF-induced increase of $\left[\mathrm{Ca}^{2+}\right]_{i}$ in human hepatoma ceils in vitro. Single-cell $\left[\mathrm{Ca}^{2+}\right]_{\mathrm{i}}$ was recorded continuously in fura-2-1oaded cells by using microflurometry, which made it possible to gauge with a reasonable degree of accuracy of the magnitude and the rapidity of intracellular $\left[\mathrm{Ca}^{2+}\right]_{i}$ increase during EGF stimulation. The $\left[\mathrm{Ca}^{2+}\right]_{\mathrm{i}}$ was represented as the ratio of emission at $510 \mathrm{~nm}$ with excitations at 350 and $380 \mathrm{~nm}(350 \mathrm{~nm} / 380 \mathrm{~nm})$, which is a monotonic function of $\left[\mathrm{Ca}^{2+}\right]_{i}$. On the other hand, the $\left[\mathrm{Ca}^{2+}\right]_{i}$ determination in cell populations was performed in fluo-3-1oaded cells by using flow cytometry, which had the advantage that measurements were made on large number of single cells, and $\left[\mathrm{Ca}^{2+}\right]_{\mathrm{i}}$ was represented as the changes of the fluo-3 fluorescence intensity. As shown in Figs 1-3, EGF-induced $\left[\mathrm{Ca}^{2+}\right]_{\mathrm{i}}$ responses in BEL-7404 cells were not only dosedependent, but also time-dependent. The data obtained by the two methods were comparable, although the falling phase of the $\left[\mathrm{Ca}^{2+}\right]_{i}$ response was more sustained in suspended cells. The explanation for such discrepancy might be that the onset of $\left[\mathrm{Ca}^{2+}\right]_{\mathrm{i}}$ response to EGF stimulation is different in individual cells. Since the $\left[\mathrm{Ca}^{2+}\right]_{\mathrm{i}}$ spikes following the initial transient $\left[\mathrm{Ca}^{2+}\right]_{\mathrm{i}}$ increase were often observed in singlecell $\left[\mathrm{Ca}^{2+}\right]_{\mathrm{i}}$ analysis, an alternative explanation is that the $\left[\mathrm{Ca}^{2+}\right]_{\mathrm{i}}$ spikes in single cells may account for the sustained $\left[\mathrm{Ca}^{2+}\right]_{\mathrm{i}}$ elevation observed in cell suspension.

Although the intracellular $\left[\mathrm{Ca}^{2+}\right]_{\mathrm{i}}$ increase in hepatocytes may be brought about either as a result of mobilizing intracellular $\mathrm{Ca}^{2+}$ or as a result of influx of the 
EGF receptor-mediated calcium increase in hepatoma cells

ion from extracellular medium[11]. The data presented in this paper demonstrated that EGF- induced $\left[\mathrm{Ca}^{2+}\right]_{\mathrm{i}}$ increase is dependent on both extracellular $\mathrm{Ca}^{2+}$ concentration and internal $\mathrm{Ca}^{2+}$ storage in endoplasmic reticulum of human hepatoma BEL-7404 cells. Chelating extracellular $\mathrm{Ca}^{2+}$ by excess EGTA partially inhibited the EGF-induced $\left[\mathrm{Ca}^{2+}\right]_{\mathrm{i}}$ increase, indicating that the $\mathrm{Ca}^{2+}$ influx occurs during EGF stimulation. There are diverse $\mathrm{Ca}^{2+}$ entry pathways in a variety of vertebrate cells according to the electrophysiological and biochemical criteria[12]. The nature of the stimulated $\mathrm{Ca}^{2+}$ entry in cultured human hepatoma BEL-7404 cells was also investigated by using $\mathrm{Mn}^{2+}$, an indicator of divalent cation entry[13]. In $\mathrm{Ca}^{2+}$. free assay buffer containing $50 \mu M \mathrm{Mn}^{2+}$, EGF induced the fluorescence quenching in fura-2-1oaded BEL-7404 cells, indicating the occurrence of bivalent cation influx during the stimulation (data not shown). $\mathrm{Mn}^{2+}$ possess three desirable properties. Firstly, it quenches fura-2 fluorescence so that its entry into the cytoplasma is readily detected. Secondly, $\mathrm{Mn}^{2+}$ entry appears to be activated under the same situation as that of $\mathrm{Ca}^{2+}$, suggesting a common pathway. Thirdly, since there is no endogenous agonist-releasable $\mathrm{Mn}^{2+}$ store, a fluorescence quench unambiguously indicates that $\mathrm{Mn}^{2+}$ enters the cytoplasm from outside of the cells and not from an internal store. On the other hand, thapsigargin (TG), a tumor- promoting sesquiterpene lactone, has been proved to be able to discharge intracellular $\mathrm{Ca}^{2+}$ stores in rat hepatocytes by specific inhibition of endoplasmic reticulum $\mathrm{Ca}^{2+}$-ATPase, as it does in many vertebrate cell types[14, 15]. Preincubation of BEL-7404 cells with $100 \mathrm{nM}$ TG for 20 min, completely abolished EGF-induced $\left[\mathrm{Ca}^{2+}\right]_{\mathrm{i}}$ responses (Tab 1), which together with the observed facts of a rapid formation of inositol-1, 4, 5-trisphosphate in EGFstimulated BEL-7404 cells (data not shown) and of the expression of antisense EGF receptor sequence in the cells suppressing the $\left[\mathrm{Ca}^{2+}\right]_{i}$ response to EGF suggested that EGF stimulation linked intracellular $\mathrm{Ca}^{2+}$ pool was covered by TG-sensitive $\mathrm{Ca}^{2+}$ pool and that EGF induced $\mathrm{Ca}^{2+}$ release was the initial response during the stimulation. The heterologous desensitization occurred in EGF-stimulated cells pretreated with TG, but not in TG-treated cells preincubated with EGF, might reflect different mechanisms of $\mathrm{Ca}^{2+}$ release from ER in EGF-treatment and TG-treatment. The former was due to inositol-1, 4, 5-trisphosphate-induced $\mathrm{Ca}^{2+}$ release, and therefore, the depleted $\mathrm{Ca}^{2+}$ pool could be recovered rapidly with the rapid metabolism of inositol-1, 4, 5-trisphosphate and reuptake of $\mathrm{Ca}^{2+}$ by $\mathrm{Ca}^{2+}$-ATPase in surface of ER. The latter was due to the net loss of $\mathrm{Ca}^{2+}$ from ER by the inhibition of ATP driven uptake of $\mathrm{Ca}^{2+}$ from cytosol and thus the exhausted $\mathrm{Ca}^{2+}$ pool could not be refilled rapidly. Besides the induction of $\mathrm{Ca}^{2+}$ discharge from endoplasmic reticulum, TG itself like EGF, triggered the $\mathrm{Ca}^{2+}$ influx in BEL- 7404 cells (Fig 4B), implicating that in either case, the decrease in $\mathrm{Ca}^{2+}$ content of the pool leads to the activation of a plasma membrane $\mathrm{Ca}^{2+}$ channel. Our finding, therefore, support the capacitative model proposed by Putney[16] that the depletion of inositol-1, 4, 5trisphosphate-sensitive $\mathrm{Ca}^{2+}$ pool activates $\mathrm{Ca}^{2+}$ influx from outside of the cells. An alternative possibility is that the increase of $\left[\mathrm{Ca}^{2+}\right]_{i}$, due to the discharge from ER 
in either case, activates the $\mathrm{Ca}^{2+}$-dependent phospholipase $\mathrm{A}_{2}$ and then activates the $\mathrm{Ca}^{2+}$ channel in plasma membrane.

Taken together, EGF receptor-mediated $\left[\mathrm{Ca}^{2+}\right]_{i}$ increase in the human hepatoma BEL-7404 cells are essentially dependent on the $\mathrm{Ca}^{2+}$ storage in endoplasmic reticulum and the internal $\mathrm{Ca}^{2+}$ release might be followed by the $\mathrm{Ca}^{2+}$ influx. The effects of the cellular $\mathrm{Ca}^{2+}$ movements on either cell growth and apoptosis in these cells are worth studying further.

\section{REFERENCES}

[1] Carpenter G. Receptors for epidermal growth factor and other polypeptide mitogens. Annu Rev Biochem 1987; 56:881-94.

[2] Nishibe S, Wahl MI, Hermandez-Sotomayor SMT, Tonks MK, Rhee SG, Carpenter G. Increase of the catalytic activity of phospholipase $\mathrm{C}_{\gamma 1}$ by tyrosine phosphorylation. Science 1990; 250:12536.

[3] Nishizuka Y. A role of protein kinase C in cell surface signal transduction and tumour promotion. Nature 1984; 308:693-7.

[4] Berridge M J, Irvine RF. Inositol trisphosphate, a novel second messenger in cellular signal transduction. Nature 1984; 312:315-21.

[5] Peppelenbosch MP, Tertoolen LGJ, den Hertog J, de Laat SW. Epidermal growth factor activates calcium channels by phospholipase $\mathrm{A}_{2} / 5$-1ipoxygenase-mediated leukotriene $\mathrm{C}_{4}$ production. Cell 1992; 69:295-303.

[6] Xu YH, Jiang WL, Peng SF. EGFR expression and EGF stimulation of proliferation in human liver carcinoma cells. Acta Biol Exp Sin 1989; 22:445-53.

[7] Xu YH, Jiang WL, Peng SF, Chen YH. Antisense EGFR sequence reverses the growth properties of human liver carcinoma cell line BEL-7404 in vitro. Cell Research 1993; 3:75-83.

[8] Shen MX, Zhang J, Zhao YL, Yang LP, Zhang XD, Zhu PH. Construction of microfluorometer and its application for measuring intracellular free calcium. Acta Physiol Sin 1994; 46:198-204.

[9] Grynkiewicz G, Poenie M, Tsien RY. A new generation of $\mathrm{Ca}^{2+}$ indicators with greatly improved fluorescence properties. J Biol Chem 1985; 260:3440-50.

[10] Minta A, Kao JPY, Tsien RY. Fluorescent indicators for cytosolic calcium based on rhodamine and fluorescein chromophores. J Biol Chem 1989; 264:8171-8.

[11] Bygrave FL, Benedetti A. Calcium: its modulation in liver by cross-talk between the actions of glucagon and calcium- mobilizing agonists. Biochem J 1993; 296:1-14.

[12] Tsien RW, Tsien RY. Calcium channels, stores, and oscillations. Annu Rev Cell Biol 1990; 6:715-60.

[13] Merritt JE, Jacob R, Hallam TJ. Use of manganese to discriminate between calcium influx and mobilization from internal stores in stimulated human neutrophils. J Biol Chem 1989; 264:1522-7.

[14] Thastrup o, Dawson AP, Scharff O, Foder B, Cullen P J, Dr ф bak BK, et al. Thapsigargin, a novel molecular probe for studying intracellular calcium release and storage. Agents Actions 1989; $27: 17-23$.

[15] Thastrup O, Cullen P J, Dr $\phi$ bak BK, Hanley MR, Dawson AP. Thapsigargin, a tumor promoter, discharge intracellular $\mathrm{Ca}^{2+}$ stores by specific inhibition of endoplasmic reticulum $\mathrm{Ca}^{2+}$-ATPase. Proc Natl Acad Sci USA 1990; 87:2466-70.

[16] Putney JW. Capacitative calcium entry revisited. Cell Calcium 1990; 11:611-24.

Received 21-7-1994. Revised 12-10-1994. Accepted 17-10-1994. 